\title{
Abortive Transduction of Motility in Proteus and Providence Strains
}

\author{
By P. C. APPELBAUM, P. F. TRICHARDT, \\ KATHRYN KRIZSANOVICH AND J. N. COETZEE \\ Department of Microbiology, University of Pretoria, Pretoria, South Africa \\ AND N. HUGO \\ Division of Life Sciences, Atomic Energy Board, Pretoria, South Africa
}

(Accepted for publication I9 November 1971)

SUMMARY

Abortive transduction of motility has been demonstrated with all members of the Proteus-Providence group of bacteria.

\section{INTRODUCTION}

Coetzee (1963) transduced the swarming property into non-swarming mutants of Proteus mirabilis with phage 34 . No abortive transductants in the form of trails (Lederberg, 1956; Stocker, 1956) were observed. Similarly, no abortive transduction (Ozeki, 1956) was encountered in auxotroph to prototroph transductions with $P$. mirabilis 13 arg $\mathrm{H}_{2}$, metE-I, cyseE-6, trp-I using phage 34.13 (Prozesky, 1968; Grabow, 1970); Proteus vulgaris 69 met-4 with phage $107 / 69$ (Coetzee, De Klerk \& Smit, I967); Proteus rettgeri R49 trp-I, leu-I, pro-I, arg-I with phage 7/R49 (Krizsanovich, De Klerk \& Smit, I969); Proteus morganii 28I 5 hi-I, ad-I, trp-I with phage M (Coetzee, Smit \& Prozesky, I966); and Providence 9295 $a d-4$, cys-I0, leu-I with phage PL25 (Coetzee et al. I966).

Böhme (1964) suggested the occurrence of abortive transduction to explain results obtained in transducing methionine auxotrophs of Proteus mirabilis, although no microcolonies were seen.

It was felt that if abortive transduction can occur in these strains the best way to demonstrate it would be by transduction of motility.

\section{METHODS}

Bacteria and phages. These are listed in Table I. The fla mutants were selected and independently isolated on semi-solid medium (0.35\% agar) after treatment of swarming strains with $N$-methyl- $N^{\prime}$-nitro- $N$-nitrosoguanidine (Adelberg, Mandel \& Chen, 1965). Non-swarming colonies were picked off on to the same medium and further investigated. Absence of flagella was confirmed by their failure to agglutinate with homologous $\mathbf{H}$ antisera and by electron microscopy. Phage lysates were prepared according to the method of Coetzee \& Sacks (1960a).

Media. Difco nutrient broth was used and the semi-solid medium contained $3.5 \mathrm{~g}$ Difco agar, $\mathrm{I} 0 \mathrm{~g}$ Bacto Tryptone and $6 \mathrm{~g} \mathrm{NaCl} / 1$ distilled water. Plates were dried with their lids removed for $\mathrm{I} h$ at $37^{\circ}$. 

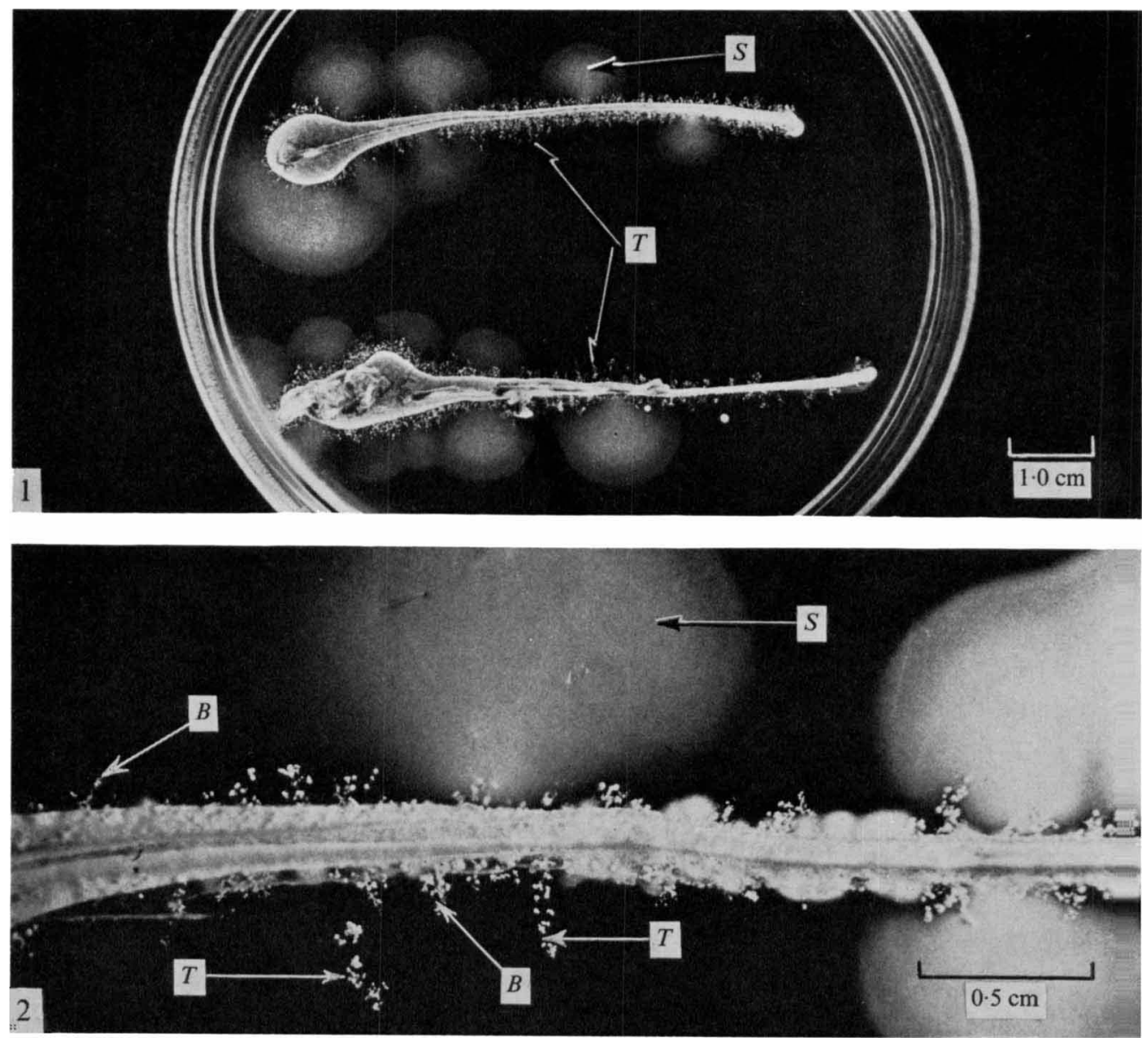

Fig. I, 2. Preparations were obtained by incubating $0.5 \mathrm{ml}$ of overnight broth culture with $0.5 \mathrm{ml}$ phage $\left(5 \times 10^{9}\right.$ p.f.u. $\left./ \mathrm{ml}\right)$. Adsorption was for $15 \mathrm{~min}$ at $30^{\circ}$. Mixtures were streaked on to semisolid agar plates and incubated overnight. Arrows indicate swarms $(S)$, trails $(T)$ and branched trails (B).

Fig. I. Proteus mirabilis fla-7 transduced to motility with wild-type $ø 34$. Numerous trails and some swarms are seen.

Fig. 2. Proteus rettgeri fla-I transduced to motility with wild-type $\varnothing 7 / \mathrm{R} 49$. A few swarms and trails (some of which are branched) are seen.

Transduction techniques. These were as described by Coetzee (1963) except for the composition of the agar $(0.35 \%)$ and the incubation temperature, which was $30^{\circ}$. Plates were incubated for 18 to $24 \mathrm{~h}$.

\section{RESULTS AND DISCUSSION}

In transduction of $f a$ recipients with wild-type phage, fan-shaped swarms and linear arrays of colonies which extended a few millimeters away from the inoculum were invariably formed (Fig. I, 2). These trails reached maximum length after about $\mathrm{I} 8 \mathrm{~h}$ incubation. Occasionally a swarm arose from one (often the most distal) of the colonies in a trail.

Trails were usually least frequent in the Proteus rettgeri, $P$. vulgaris and Providence strains and most abundant in $P$. mirabilis and $P$. morganii, where they often far outnumbered the 
Table I. Proteus and Providence transducing systems

\begin{tabular}{|c|c|c|c|}
\hline Parent strain & Mutants & Phage & Reference \\
\hline $\begin{array}{l}\text { Proteus mirabilis } 13 \\
\text { Proteus morganii } 2815\end{array}$ & $\begin{array}{l}f a \mathrm{I}-\mathrm{I} 3 \\
f a \mathrm{I}-5\end{array}$ & $\begin{array}{l}34 \\
\mathbf{M}\end{array}$ & $\begin{array}{l}\text { Coetzee \& Sacks (1960a) } \\
\text { Coetzee et al. (I966) }\end{array}$ \\
\hline Proteus rettgeri $\mathrm{R} 49$ & $f a \mathrm{I}, 2$ & $7 / R_{49}$ & Krizsanovich et al. (1969) \\
\hline Proteus vulgaris 69 & $f a \mathrm{I}_{2}$ & $107 / 69$ & Coetzee et al. (1967) \\
\hline Providence 9295 & $f a{ }_{\mathrm{I}}-5$ & PL 25 & Coetzee et al. (1966) \\
\hline
\end{tabular}

swarms. Colonies picked from trails and inoculated separately on agar either developed into a single colony or swarmed. The trails resembled the abortive transduction of motility described by Stocker (1956) and Lederberg (1956) in Salmonella and by Armstrong \& Adler (1967) in Escherichia coli. Some trails branched, for which a possible explanation is that daughter cells without the non-replicating transduced chromosome fragment inherited sufficient wild-type gene product to render them motile in the very soft agar (Stocker, 1956). In transduction between mutants in the $P$. mirabilis, $P$. morganii and Providence strains some crosses yielded swarms but no trails.

In such cases the lesions in the donor and recipient genomes could have been in the same cistron. This effect was usually reciprocal, but a few mutants of Proteus mirabilis showed non-reciprocal complementation. This phenomenon has also been encountered by Armstrong \& Adler (1967) in Escherichia coli and by Iino \& Enomoto (1966) in Salmonella. Using the mutants listed in Table I it was possible provisionally to divide the fla mutants of both $P$. mirabilis and Providence into four complementation groups while the $f a$ mutants of $P$. morganii, $P$. vulgaris and $P$. rettgeri each fell into two groups.

Two types of controls were employed. In the one the phage used was prepared on the recipient and in the other the phage-suspension was replaced by an equal volume of broth. These usually produced no swarms. Occasionally broth control plates of Proteus mirabilis and $P$. vulgaris fla mutants showed a few trails. This occurred in the absence of phage a situation similar to that encountered by Armstrong \& Adler (1967) with some mot mutants of Escherichia coli.

Quadling \& Stocker (1957) demonstrated that certain Proteus ' $O$ ' strains gave rise to satellite micro-colonies, and the existence of the 'Tröpfchenform' colonies of Proteus hauseri (Coetzee \& Sacks, I960 b) may be a similar phenomenon. The occurrence of these spontaneous trails does not reduce the significance of trails encountered in the transduction experiments, which were always much more numerous and reproducible. Thus in experiments with $P$. mirabilis or $P$. vulgaris it was possible to divide $f l a$ mutants into groups which consistently gave o to 50,50 to 250 or 250 to 500 trails with phage prepared on other mutants.

Failure to detect trails in the previous Proteus mirabilis experiments (Coetzee, 1963) may have been due to the higher agar concentration $(0.6 \%)$ and the higher incubation temperature $\left(37^{\circ}\right)$ used. Both of these variables are known to affect flagellar formation and function in Proteus spp. (Coetzee \& De Klerk, I964).

We have now demonstrated the abortive transduction of motility with all members of the Proteus-Providence group, but the reason for failure to demonstrate the phenomenon with other markers has to be determined.

This work was aided by grants to J.N.C. from the South African Medical Research Council. 


\section{REFERENCES}

Adelberg, E. A., Mandel, M. \& Chen, G. C. C. (1965). Optimal conditions for mutagenesis by $N$-methyl$N^{\prime}$-nitro- $N$-nitrosoguanidine in Escherichia coli $\mathrm{K}-\mathrm{I}$ 2. Biochemical and Biophysical Research Communications $\mathbf{1 8}, 788-795$.

Armstrong, J. B. \& AdLer, J. (1967). Genetics of motility in Escherichia coli: complementation of paralyzed mutants. Genetics 56, 363-373.

Böнme, H. (1964). Über den Einfluss von Mutationen im Genom des Donorstammes auf die Transduktionsfähigkeit des Proteus-phagen $\pi$ I. Sonderdruck aus: Struktur und Funktion des genetischen Materials. Erwin-Baur-Gedächtnisvorlesungen, vol. III, pp. I07-I I I. Berlin: Akademie-Verlag.

Coetzee, J. N. (1963). Transduction of swarming in Proteus mirabilis. Journal of General Microbiology 33, I-7.

COETzee, J. N. \& De KLeRK, H. C. (I964). Effect of temperature on flagellation, motility and swarming of Proteus. Nature, London 202, 2 I I-2I 2.

Coetzee, J. N., De Klerk, H. C. \& Smit, J. A. (1967). A transducing bacteriophage for Proteus vulgaris. Journal of General Virology $\mathbf{r}, 56 \mathrm{I}-564$.

Coetzee, J. N. \& SACKs, T. G. (1960a). Transduction of streptomycin resistance in Proteus mirabilis. Journal of General Microbiology 23, 445-455.

Coetzee, J. N. \& SAcks, T. G. (I960b). Morphological variants of Proteus hauseri. Journal of General Microbiology 23, 209-216.

Coetzee, J. N., Smit, J. A. \& Prozesky, O. W. (I966). Properties of Providence and Proteus morganii transducing phages. Journal of General Microbiology 44, I67-1 76.

Grabow, W. O. K. (1970). Genetic Studies of Methionine Synthesis in Proteus mirabilis. D. Sc. Thesis, University of Pretoria, South Africa.

IINo, T. \& Еnомото, M. (I966). Genetical studies of non-flagellate mutants of Salmonella. Journal of General Microbiology 43, 315-327.

Krizsanovich, K., De KleRK, H. C. \& Smit, J. A. (1969). A transducing bacteriophage for Proteus rettgeri. Journal of General Virology 4, 437-439.

LEDERBERG, J. (1956). Linear inheritance in transductional clones. Genetics 4r, 845-87I.

OzEKI, H. (1956). Abortive transduction in purine-requiring mutants of Salmonella typhimurium. In Genetic Studies With Bacteria, pp. 97-106. Washington D.C.: Carnegie Institution of Washington Publication no. 6I2.

Prozesky, O. W. (1968). Transductional analysis of arginineless mutants in Proteus mirabilis. Journal of General Microbiology 54, I 27-I43.

QUAdling, C. \& Stocker, B. A. D. (I957). The occurrence of rare motile bacteria in some non-motile Salmonella strains. Journal of General Microbiology $\mathbf{1 7}, 424-436$.

Stocker, B. A. D. (1956). Abortive transduction of motility in Salmonella: a non-replicated gene transmitted through many generations to a single descendant. Journal of General Microbiology r5, 575-598. 